\title{
Literature ReVIew Concepts and objects of awareness in Alzheimer's disease: an updated systematic review
}

\author{
Conceitos e objetos da consciência na doença de \\ Alzheimer: uma revisão sistemática atualizada \\ Isabel B. Lacerda', Maria Fernanda B. Sousa', Raquel L. Santos', Marcela M. L. Nogueira', \\ Marcia C. N. Dourado
}

\section{Keywords}

Awareness, objects of awareness, anosognosia, dementia, Alzheimer.

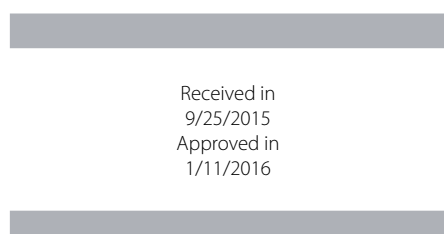

DOI: $10.1590 / 0047-2085000000110$

\section{ABSTRACT}

Objectives: To compare and discuss the objects of awareness in Alzheimer's disease (AD): awareness of cognitive deficits, of functional activities, of social-emotional functioning and behavioral impairment. Methods: A search in the PsycINFo, Pilots, PubMed/Medline and ISI electronic databases according to Prisma methodology was performed. We included studies about awareness in people with AD published between 2010 and 2015, with the combination of keywords: "Alzheimer AND awareness of deficits", "Alzheimer AND anosognosia", "Alzheimer AND insight", "dementia AND awareness of deficits", "dementia AND anosognosia", "dementia AND insight". The articles were categorized according to the specific object of awareness. Results: Seven hundred and ten records were identified and, after application of the exclusion criteria, 191 studies were retrieved for potential use. After excluding the duplicates, 46 studies were included. Most studies assessed the cognitive domain of awareness, followed by the functional, social-emotional, and behavioral impairment domains. Memory deficits were not sufficient to explain impaired awareness in AD. Longitudinal studies did not find discrepancies between patients and caregivers' reports, indicating that awareness is not related to cognition. Conflicting findings were observed, including the relation between awareness, mood, severity of disease, and personal characteristics. Conclusions: The studies show lack of conceptual consensus and significant methodological differences. The inclusion of samples without differentiation of dementia etiology is associated to symptomatic differences, which affect awareness domains. Awareness in AD is a complex and multidimensional construct. Different objects elicit different levels of awareness.

\section{RESUMO}

Objetivos: Comparar e discutir os objetos de consciência na doença de Alzheimer (DA): consciência dos déficits cognitivos, das atividades funcionais, do funcionamento socioemocional e prejuízos comportamentais. Métodos: Realizou-se uma busca nas bases de dados PsycINFo, Pilots, PubMed/Medline e ISI de acordo com a metodologia do Prisma. Os artigos incluídos, publicados entre 2010 e 2015, avaliavam a consciência na DA com as combinações de palavras-chave: "Alzheimer AND consciência do déficit", "Alzheimer AND anosognosia", "Al-

1 Federal University of Rio de Janeiro (UFRJ), Institute of Psychiatry, Center for Alzheimer's Disease and Related Disorders, Rio de Janeiro, RJ, Brazil.

Address for correspondence: Isabel B. Lacerda Rua Gabriel Garcia Moreno, 541, casa 1, São Conrado 22610-360 - Rio de Janeiro, RJ, Brazil Telephone: (55 21) 99224-2572 E-mail: isabelbvll@hotmail.com 


\section{Palavras-chave}

Consciência, objetos da consciência, anosognosia, demência, Alzheimer. zheimer AND insight", "demência AND consciência do déficit", "demência AND anosognosia", "demência AND insight". Os artigos foram categorizados conforme os objetos específicos da consciência. Resultados: Setecentos e dez estudos foram identificados e, após a aplicação dos critérios de exclusão, 191 foram selecionados. Após a exclusão dos duplicados, 46 estudos foram incluídos. A maioria dos estudos avaliou o domínio cognitivo da consciência, seguido do funcional, do funcionamento socioemocional e prejuízos comportamentais. Déficits na memória não se mostraram suficientes para explicar o prejuízo da consciência na DA. Os estudos longitudinais não encontraram discrepâncias entre os relatos de pacientes e cuidadores, indicando que a consciência não está relacionada à cognição. Observaram-se controvérsias nos resultados na relação entre consciência, humor, gravidade da doença e características pessoais. Conclusões: Os estudos demonstraram falta de consenso conceitual e diferenças metodológicas significativas. A inclusão de amostras sem diferenciação da etiologia demencial está associada a diferenças sintomáticas que afetam os domínios da consciência. A consciência na DA é um constructo complexo e multidimensional. Diferentes objetos suscitam diferentes níveis de consciência.

\section{INTRODUCTION}

Empirical research has recently focused on exploring awareness in people with dementia $(P w D)^{1,2}$. Awareness is the recognition of changes caused by the deficits related to the disease process. It includes three dimensions: the ability to recognize a specific deficit, the emotional response to the difficulties and the ability to understand the impact of the impairment in the functional activities ${ }^{3,4}$. This construct integrates biological, psychological and social levels and is not simply as a symptom of illness ${ }^{3}$.

Awareness may be considered a relational concept. It can only be expressed in its relation to something, such as to the pathological state or non-morbid experience ${ }^{5}$. Three main factors determine clinical phenomena of awareness: the underlying concept selected by the clinician/researcher, the measure used to elicit it, and the specific object of awareness chosen ${ }^{6,7}$. These factors may be particularly variable in dementia research.

The objects of awareness may range from physical attributes of the environment or internal states to factors of one's own functioning or situation, external events, mental representations and aspects of self ${ }^{8}$. Therefore, awareness cannot be isolated from its object. This complexity is captured because different 'objects' will determine different kinds of judgments'.

Impaired awareness is a complex and multidimensional phenomenon, commonly reported as a clinical feature of dementia, and can range from mild to severe stages ${ }^{2}$. Studies focusing on clinical correlates and predictors of unawareness have produced inconclusive findings. Probably, the several conceptual models of awareness and methodological differences, such as heterogeneity of sample and level of disease severity may explain these uncertain findings 9 .

It is essential to understand the differences between each object of awareness and of their specific traits, as it may be helpful for the improvement of strategies focused on the manage- ment of $\mathrm{PwD}{ }^{1,6,10}$. In this context, this systematic review is aimed at exploring the different objects of awareness in Alzheimer's disease (AD). We consider that different objects of awareness raise different phenomena. Our primary goal is to systemize the results of the researches involving awareness according to each specific object. We proposed to discuss the concepts and domains used to evaluate types of awareness, such as awareness of cognitive deficits, of social-emotional status and behavioral impairment and awareness of functional activities.

\section{METHODS}

This systematic review is according to the Preferred Reporting Items for Systematic Reviews and Meta-Analyses (PRISMA) 1 . The search for literature was undertaken on April $5^{\text {th }}, 2015$, using PsycINFo, Pilots, PubMed/Medline and ISI electronic databases. The search keywords included "Alzheimer", "dementia", "awareness of deficits", "insight" and "anosognosia" in the following combinations: "Alzheimer AND awareness of deficits", "Alzheimer AND anosognosia", "Alzheimer AND insight", "dementia AND awareness of deficits", "dementia AND anosognosia", "dementia AND insight".

Inclusion criteria were: (1) original cross-sectional or longitudinal quantitative researches, (2) studies on participants with AD diagnosis, (3) reports written in English or Portuguese and (4) publications from January 2010 to April 2015. The exclusion criteria were: (1) opinion papers or reviews, (2) participants with pre-clinical dementia conditions, other dementia or clinical pathologies and psychiatric comorbidities, (3) other impairments not related to awareness, (4) studies focused only on pharmacologically interventions or rehabilitation issues and (5) studies without full text.

Two authors (RLS and MLN) independently screened titles and abstracts to identify eligible papers. When the information was not enough to identify the inclusion and/or 
exclusion criteria, we retrieved the full text paper. We excluded all studies that clearly did not meet all inclusion criteria or that met at least one of the exclusion criteria. Afterwards, two authors (RLS and MCND) independently reviewed the full publications of the remaining papers and held consensus meetings to discuss any disagreement and to reach a consensus about inclusion. When necessary, a third co-author of this paper (MFBS) clarified study eligibility.

\section{RESULTS}

Initially, 710 records were identified through database searching: 13 in PsycINFo, 1 in Pilots, 247 in PubMed/Medline and 449 in ISI. The 191 studies that remained after application of the exclusion criteria were retrieved for potential use and the information of the full-text version of each study was evaluated. Cross-referencing of reference lists of all selected papers was undertaken. After duplicates were removed, the total number of studies was reduced to 46. The flow diagram about the different phases of the systematic review is shown in Figure 1.

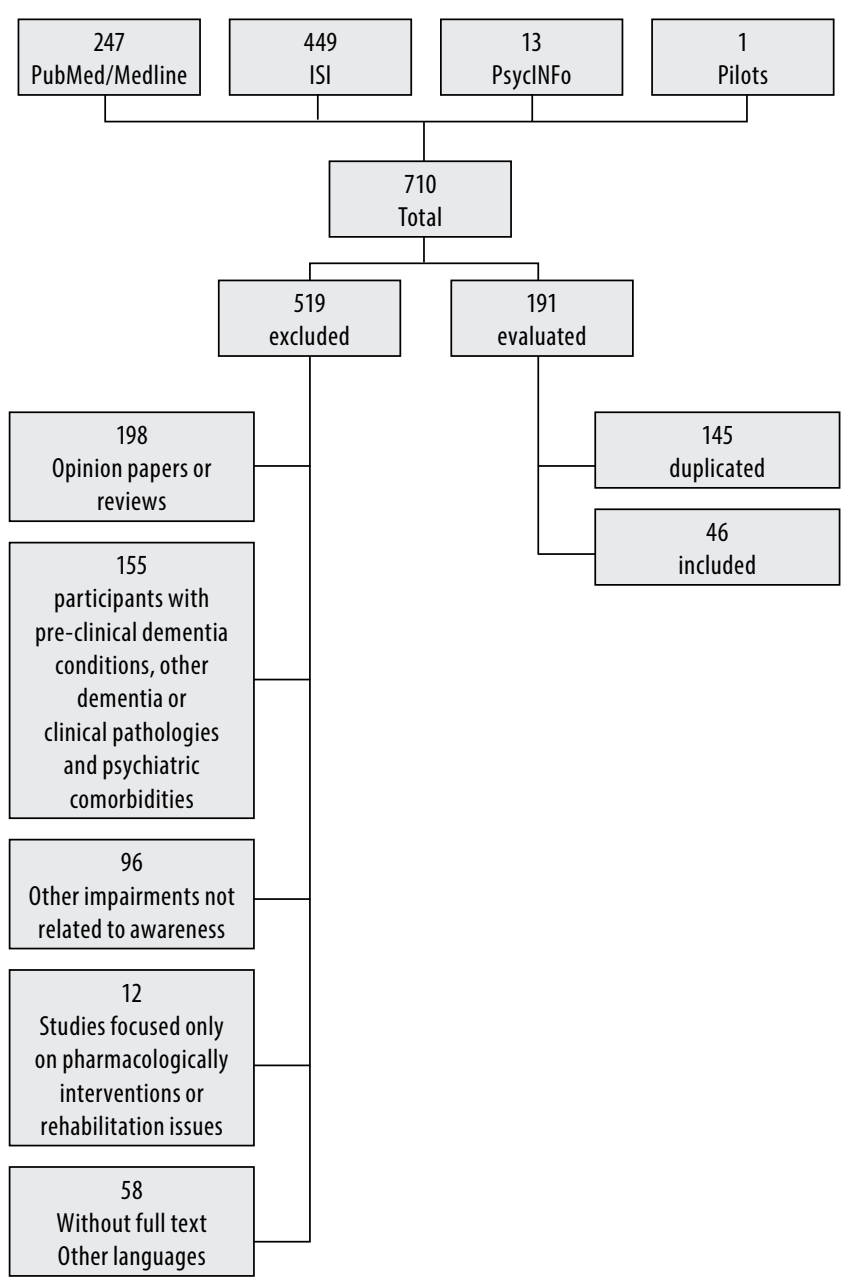

Figure 1. Flow of information through the different phases of a systematic review.
The selected studies were organized in Table 1.

Different concepts were used to define the construct of awareness ${ }^{12-20}$, anosognosia ${ }^{21-32}$, self-awareness ${ }^{33,34}$, self -appraisal ${ }^{35}$, insight ${ }^{36,37}$, cognitive insight ${ }^{38}$, metacognition ${ }^{39-41}$, unawareness of deficits ${ }^{42}$, awareness of deficit ${ }^{43,44}$, awareness of disease ${ }^{1,45}$, awareness of functioning ${ }^{46}$, awareness of cognitive deficits ${ }^{47}$, awareness of disabilities ${ }^{48}$, awareness of performance ${ }^{49}$, unawareness of memory ${ }^{42,50-52}$, anosognosia of memory $^{53}$, awareness of memory deficits ${ }^{54,55}$, awareness of memory function and functional abilities ${ }^{56}$, unawareness of psychosis or behavioral problems ${ }^{42}$.

Awareness was defined as the capability of an individual to accurately evaluate and report about his abilities and limitations ${ }^{12}$. Awareness of disease was defined as the ability to perceive changes in oneself and/or in functional activities caused by deficits associated with the disease process ${ }^{45}$. Self-awareness referred to the capacity to reflect upon and identify with one's own abilities, attitudes and behavior ${ }^{33}$. Self-appraisal was related to impaired awareness of one's own abilities ${ }^{35}$. Cognitive insight was defined as a PwD current capacity to evaluate his or her anomalous experiences and atypical interpretations of events ${ }^{38}$. Metacognition was the knowledge about cognition, including the ability to think about one's own basic cognitive abilities (such as episodic memory or executive functions) ${ }^{41}$. It was also defined as a process by which we understand and alter our own thinking ${ }^{39}$.

Some concepts were used to define impairment in awareness, which may range from general to specific impairments, such as anosognosia of memory. Thus, loss of insight was defined as a lack of awareness of mental symptoms, which could be either frank denial or unconcern about consequences ${ }^{37}$. Meanwhile, Anosognosia was defined as an inability of patients to appreciate or recognize their own deficits in sensory, perceptual, motor, behavioral, or cognitive functioning ${ }^{32}$. In a strict sense, it referred to inability to recognize deficits or realize their extent ${ }^{29}$. Reduced awareness about cognitive deficits or illness, was also termed anosognosia, and ranges from the diagnosis and the condition itself to reduced awareness of deficits in specific abilities ${ }^{49}$. Moreover, unawareness of deficits was defined as inability to recognize the presence or appreciate the severity of deficits in sensory, perceptual, motor, affective, or cognitive functioning ${ }^{42}$.

Most of the studies assessed awareness of cognitive deficits. Among them, 13 evaluated only this domain $20,23,27,38,39,41,44,47,50-53,55$. Ten studies evaluated awareness of cognitive and functional deficits domains ${ }^{1,18,20,33-35,40,45,46,54}$, nine assessed cognitive and social-emotional functioning domains $12,13,17,24,28,30,36,37,49$, and three focused on cognitive and behavioral impairment domains ${ }^{14,16,42}$. Three researches compared awareness of cognitive, functional and behavioral impairment domains $22,25,32$ and four studied the recognition of cognitive, functional, and social-emotional 
functioning 15,19,29,43. Two studies assessed only awareness of social-emotional functioning ${ }^{21,26}$, one evaluated only beha- vioral impairment ${ }^{31}$, and the other one just assessed awareness of functional deficits ${ }^{48}$.

Table 1. Selected studies

\begin{tabular}{|c|c|c|c|c|c|c|}
\hline Author/year & Term used & Participants & $\begin{array}{l}\text { Study } \\
\text { Design }\end{array}$ & Domains & $\begin{array}{l}\text { Awareness } \\
\text { measurement }\end{array}$ & Results \\
\hline $\begin{array}{l}\text { 1) Lehrner et al., } \\
2015^{54}\end{array}$ & $\begin{array}{l}\text { Awareness of } \\
\text { memory deficits }\end{array}$ & $\begin{array}{l}280 \mathrm{SCD} \\
137 \mathrm{aMCl} \\
181 \mathrm{naMCl} \\
43 \mathrm{AD} \\
28 \mathrm{PD}-\mathrm{ch} \\
29 \mathrm{PD}-\mathrm{aMCl} \\
58 \mathrm{PD}-\mathrm{naMCl} \\
211 \mathrm{HC}\end{array}$ & Cross-sectional & $\begin{array}{l}\text { Cognition } \\
\text { Functional }\end{array}$ & $\begin{array}{l}\text { VSRT } \\
\text { Delayed Recall } \\
\text { scores from FAI } \\
\text { scores }\end{array}$ & $\begin{array}{l}\text { The strongest associations were observed between } \\
\text { awareness and the domain memory. Further small } \\
\text { but significant correlations were also observed for the } \\
\text { domains attention, language and executive function }\end{array}$ \\
\hline $\begin{array}{l}\text { 2) Mograbi et al., } \\
2015^{50}\end{array}$ & $\begin{array}{l}\text { Unawareness of } \\
\text { memory }\end{array}$ & $829 A D$ & Cross-sectional & Cognition & $\begin{array}{l}\text { Discrepancies } \\
\text { between } \\
\text { Self-rating and } \\
\text { informant rating, } \\
\text { and between } \\
\text { people self- } \\
\text { rating and their } \\
\text { performance }\end{array}$ & $\begin{array}{l}\text { The self-report/actual performance variable showed a } \\
\text { relationship with cognitive impairments, such as fluency } \\
\text { in China and visuospatial abilities in Latin America and } \\
\text { India, and behavioral symptoms, such as mania in Latin } \\
\text { America and hallucinations in China }\end{array}$ \\
\hline $\begin{array}{l}\text { 3) Vogel et al., } \\
2015^{14}\end{array}$ & Awareness & $95 \mathrm{AD}$ & Longitudinal & $\begin{array}{l}\text { Cognition } \\
\text { Behavioral }\end{array}$ & $A Q-D$ & $\begin{array}{l}\text { Despite overall cognitive decline, awareness was stable } \\
\text { over three years in many cases and in some cases even } \\
\text { improved awareness was found }\end{array}$ \\
\hline $\begin{array}{l}\text { 4) Sousa et al., } \\
2015^{1}\end{array}$ & $\begin{array}{l}\text { Awareness of } \\
\text { disease }\end{array}$ & $\begin{array}{l}69 \text { AD (baseline) } \\
55 \text { AD (follow-up) }\end{array}$ & Longitudinal & $\begin{array}{l}\text { Cognition } \\
\text { Functional }\end{array}$ & AISPDD & $\begin{array}{l}\text { The first moment of evaluation showed that impairment } \\
\text { in awareness was associated to deficits in ADL, cognitive } \\
\text { impairments, and higher PwD quality of life ratings. At } \\
\text { follow up, impaired awareness was associated to deficits } \\
\text { in ADLs, and caregivers' QoL }\end{array}$ \\
\hline $\begin{array}{l}\text { 5) Mak et al., } \\
2015^{30}\end{array}$ & Anosognosia & $\begin{array}{l}36 \mathrm{AD} \\
20 \mathrm{MCl} \\
30 \mathrm{HC}\end{array}$ & Cross-sectional & $\begin{array}{l}\text { Cognition } \\
\text { Social-emotional }\end{array}$ & $A Q-D$ & $\begin{array}{l}\text { Anosognosia was associated with reduced global } \\
\text { cognition and increased apathy in the AD group }\end{array}$ \\
\hline $\begin{array}{l}\text { 6) Chen et al., } \\
2014^{42}\end{array}$ & $\begin{array}{l}\text { Unawareness of } \\
\text { deficits } \\
\text { unawareness of } \\
\text { memory deficits } \\
\text { and unawareness } \\
\text { of psychosis } \\
\text { or behavioral } \\
\text { problems }\end{array}$ & $55 \mathrm{AD}$ & Cross-sectional & $\begin{array}{l}\text { Cognition } \\
\text { Behavioral }\end{array}$ & GRAD & $\begin{array}{l}\text { Apathy was associated with neither unawareness of } \\
\text { memory deficits nor unawareness of psychosis and } \\
\text { behavioral problems. Depression was correlated only with } \\
\text { unawareness of memory deficits }\end{array}$ \\
\hline $\begin{array}{l}\text { 7) Clare et al., } \\
2012^{20}\end{array}$ & $\begin{array}{l}\text { Awareness of } \\
\text { memory function } \\
\text { and functional } \\
\text { abilities }\end{array}$ & $101 \mathrm{AD}$ & Cross-sectional & $\begin{array}{l}\text { Cognition } \\
\text { Functional }\end{array}$ & MARS-MFS & $\begin{array}{l}\text { Two areas of awareness - evaluative judgements } \\
\text { of memory function and evaluative judgements of } \\
\text { functional abilities show small to medium bivariate } \\
\text { correlations with self-reported QoL-AD, with greater } \\
\text { awareness related to lower } Q 0 \mathrm{~L}\end{array}$ \\
\hline $\begin{array}{l}\text { 8) Horning et al., } \\
2014^{36}\end{array}$ & Insight & $107 \mathrm{AD}$ & Cross-sectional & $\begin{array}{l}\text { Cognition } \\
\text { Social-emotional }\end{array}$ & NRS & $\begin{array}{l}\text { Insight over and above cognitive functioning appears } \\
\text { to play a role in an AD patient's experience of depressed } \\
\text { mood, anxiety, and apathy }\end{array}$ \\
\hline $\begin{array}{l}\text { 9) Conde-Sala et } \\
\text { al., } 2014^{22}\end{array}$ & Anosognosia & $141 \mathrm{AD}$ & Cross-sectional & $\begin{array}{l}\text { Cognition } \\
\text { Behavioral } \\
\text { Functional }\end{array}$ & $A Q-D$ & $\begin{array}{l}\text { Patients with mild deterioration presented less } \\
\text { anosognosia, more depression and a QoLp rating that } \\
\text { was closer to that of caregivers. Among patients the } \\
\text { presence of anosognosia was associated with better } \\
\text { ratings of QoLp and with greater severity. Depression and } \\
\text { anosognosia were inversely correlated among patients }\end{array}$ \\
\hline $\begin{array}{l}\text { 10) Conde-Sala et } \\
\text { al., } 2014^{23}\end{array}$ & Anosognosia & $119 A D$ & Longitudinal & Cognition & CAMDEX & $\begin{array}{l}\text { Anosognosia was associated with cognitive impairment, } \\
\text { and was associated with better perceived QoL-p in } \\
\text { moderate dementia, whereas cognitive status did } \\
\text { not influence the ratings of these patients, moreover } \\
\text { anosognosia and cognition act as independent variables } \\
\text { in relation to perceived quality of life }\end{array}$ \\
\hline $\begin{array}{l}\text { 11) Rosen et al., } \\
2014^{39}\end{array}$ & Metacognition & $\begin{array}{l}12 \mathrm{bvFTD} \\
14 \mathrm{AD} \\
35 \mathrm{HC}\end{array}$ & Cross-sectional & Cognition & $\begin{array}{l}\text { 20-item paired } \\
\text { associates } \\
\text { learning paradigm }\end{array}$ & $\begin{array}{l}\text { Significant impairments in feeling of knowing accuracy } \\
\text { in bVFTD and AD }\end{array}$ \\
\hline
\end{tabular}




\begin{tabular}{|c|c|c|c|c|c|c|}
\hline Author/year & Term used & Participants & $\begin{array}{l}\text { Study } \\
\text { Design }\end{array}$ & Domains & $\begin{array}{l}\text { Awareness } \\
\text { measurement }\end{array}$ & Results \\
\hline $\begin{array}{l}\text { 12) Gambina et al., } \\
2014^{47}\end{array}$ & $\begin{array}{l}\text { Awareness of } \\
\text { cognitive deficits }\end{array}$ & $79 A D$ & Cross-sectional & Cognition & $A Q-D$ & $\begin{array}{l}\text { Cognitive deficits in executive function, memory and } \\
\text { language may mediate the association between capacity } \\
\text { and awareness }\end{array}$ \\
\hline $\begin{array}{l}\text { 13) Marková et al., } \\
2014^{19}\end{array}$ & Awareness & 101 PwD & Cross-sectional & $\begin{array}{l}\text { Cognition } \\
\text { Social-emotional } \\
\text { Functional }\end{array}$ & $\begin{array}{l}\text { MARS } \\
\text { FAQ } \\
\text { SEQ }\end{array}$ & $\begin{array}{l}\text { Awareness of memory shows the greatest proportion } \\
\text { of negative discrepancies (overestimation of function). } \\
\text { Awareness of ADL also shows that a large proportion of } \\
\text { negative discrepancies are obtained but in contrast to } \\
\text { awareness of memory there is greater variation between } \\
\text { individuals and more concordant responses. Awareness } \\
\text { of socio-emotional in comparison with the other } \\
\text { awareness phenomena shows a higher proportion of } \\
\text { positive discrepancies observed in a substantial number } \\
\text { of participants }\end{array}$ \\
\hline $\begin{array}{l}\text { 15) Degirmenci et } \\
\text { al., } 2013^{38}\end{array}$ & Cognitive insight & $\begin{array}{l}30 \mathrm{AD} \\
15 \mathrm{HC}\end{array}$ & Cross-sectional & Cognition & $\mathrm{BCIS}$ & $\begin{array}{l}\text { Self-reflectiveness and self-certainty scores were } \\
\text { significantly lower than the controls in patients with AD }\end{array}$ \\
\hline $\begin{array}{l}\text { 16) Zamboni et al., } \\
2013^{33}\end{array}$ & Self-awareness & $\begin{array}{l}17 \mathrm{MCl} \\
17 \mathrm{AD} \\
17 \mathrm{HC}\end{array}$ & Cross-sectional & $\begin{array}{l}\text { Functional } \\
\text { Cognition }\end{array}$ & $\begin{array}{l}\text { Discrepancies } \\
\text { between } \\
\text { Self-rating and } \\
\text { informant rating }\end{array}$ & $\begin{array}{l}\text { Dysfunction of a network involving medial prefrontal } \\
\text { and anterior temporal cortices is associated with the } \\
\text { failure in mechanisms necessary for correct and updated } \\
\text { self-awareness }\end{array}$ \\
\hline $\begin{array}{l}\text { 17) Massimo et al., } \\
2013^{35}\end{array}$ & Self-appraisal & $\begin{array}{l}49 \text { bvFTD } \\
73 \mathrm{AD}\end{array}$ & Cross-sectional & $\begin{array}{l}\text { Functional } \\
\text { Cognition }\end{array}$ & $\begin{array}{l}\text { Discrepancies } \\
\text { between } \\
\text { Self-rating and } \\
\text { informant rating, } \\
\text { and between } \\
\text { people self- } \\
\text { rating and their } \\
\text { performance }\end{array}$ & $\begin{array}{l}\text { BvFTD show significant deficits in self-appraisal across } \\
\text { multiple cognitive domains, suggesting a fundamental } \\
\text { impairment in self-evaluation and self-monitoring. } \\
\text { Observed impaired self-appraisal only for episodic } \\
\text { memory in the AD group, suggesting a domain-specific } \\
\text { impairment for these patients }\end{array}$ \\
\hline $\begin{array}{l}\text { 18) Amanzio et al., } \\
2013^{43}\end{array}$ & $\begin{array}{l}\text { Awareness of } \\
\text { deficits }\end{array}$ & $\begin{array}{l}117 \mathrm{AD} \\
117 \mathrm{HC}\end{array}$ & Cross-sectional & $\begin{array}{l}\text { Cognition } \\
\text { Social-emotional } \\
\text { Functional }\end{array}$ & $A Q-D$ & $\begin{array}{l}\text { There is a role for subcomponents of executive functions } \\
\text { in impaired awareness of deficits such as inhibition, self- } \\
\text { monitoring and set-shifting }\end{array}$ \\
\hline $\begin{array}{l}\text { 19) Mårdh et al., } \\
2013^{40}\end{array}$ & $\begin{array}{l}\text { Metacognition } \\
\text { Awareness of } \\
\text { disease }\end{array}$ & $\begin{array}{l}15 A D \\
15 H C\end{array}$ & Cross-sectional & $\begin{array}{l}\text { Cognition } \\
\text { Functional }\end{array}$ & $\begin{array}{l}\text { Self-rating and } \\
\text { informant rating }\end{array}$ & $\begin{array}{l}\text { Although patients were aware of their disease, they were } \\
\text { not able to realize the practical consequences of their } \\
\text { deficit }\end{array}$ \\
\hline $\begin{array}{l}\text { 20) Verhülsdonk } \\
\text { et al., } 2013^{24}\end{array}$ & Anosognosia & $49 A D$ & Cross-sectional & $\begin{array}{l}\text { Cognition } \\
\text { Social-emotional }\end{array}$ & $A Q-D$ & $\begin{array}{l}\text { Patients had depressive symptoms but were unaware } \\
\text { of them in the sense of an "affective" anosognosia. The } \\
\text { phenomenon of anosognosia affects not only deficits } \\
\text { in cognition and daily functioning, but that it can also } \\
\text { manifest itself as non-recognition of affective symptoms }\end{array}$ \\
\hline $\begin{array}{l}\text { 21) Conde-Sala et } \\
\text { al., } 2013^{25}\end{array}$ & Anosognosia & $164 A D$ & Cross-sectional & $\begin{array}{l}\text { Cognition } \\
\text { Behavioral } \\
\text { Functional }\end{array}$ & $A Q-D$ & $\begin{array}{l}\text { More symptoms on the NPI, less depression and greater } \\
\text { deficits in ADL, are the most relevant variables that may } \\
\text { predict anosognosia. Greater awareness of deficits is } \\
\text { related to a reactive depressive mood, especially in the } \\
\text { early stages of dementia }\end{array}$ \\
\hline $\begin{array}{l}\text { 22) Van Vliet et al., } \\
2013^{12}\end{array}$ & Awareness & $\begin{array}{l}142 \text { Y0-AD } \\
126 L 0-A D\end{array}$ & Longitudinal & $\begin{array}{l}\text { Cognition } \\
\text { Social-emotional }\end{array}$ & GRAD & $\begin{array}{l}\text { Patients with Y0-AD have higher levels of awareness } \\
\text { compared with } L 0-A D \text {. Intact awareness was associated } \\
\text { with depressive symptoms, and this effect was more } \\
\text { pronounced in YO-AD compared with LO-AD }\end{array}$ \\
\hline $\begin{array}{l}\text { 23) Maki et al., } \\
2012^{34}\end{array}$ & Self-awareness & $\begin{array}{l}12 \mathrm{AP} \\
23 \mathrm{AD} \text { mild } \\
18 \mathrm{AD} \text { moderate } \\
53 \text { caregivers }\end{array}$ & Cross-sectional & $\begin{array}{l}\text { Cognition } \\
\text { Functional }\end{array}$ & $A Q-D$ & $\begin{array}{l}\text { Mild AD were generally aware of their deficits even if their } \\
\text { assessment was insufficient. In moderate AD, insufficient } \\
\text { awareness of deficits was related to memory, and time } \\
\text { and spatial orientation }\end{array}$ \\
\hline $\begin{array}{l}\text { 24) Mograbi et al., } \\
2012^{52}\end{array}$ & $\begin{array}{l}\text { Unawareness of } \\
\text { memory }\end{array}$ & 15,022 PwD & Cross-sectional & Cognition & $\begin{array}{l}\text { Discrepancies } \\
\text { between } \\
\text { Self-rating and } \\
\text { informant rating, } \\
\text { and between } \\
\text { people self- } \\
\text { rating and their } \\
\text { performance }\end{array}$ & $\begin{array}{l}\text { Unawareness should be seen not only as a common } \\
\text { neurobiological feature of dementia, increasing with } \\
\text { severity of dementia, but also as a phenomenon } \\
\text { influenced by social and cultural factors }\end{array}$ \\
\hline
\end{tabular}




\begin{tabular}{|c|c|c|c|c|c|c|}
\hline Author/year & Term used & Participants & $\begin{array}{l}\text { Study } \\
\text { Design }\end{array}$ & Domains & $\begin{array}{l}\text { Awareness } \\
\text { measurement }\end{array}$ & Results \\
\hline $\begin{array}{l}\text { 25) Clare et al., } \\
2012^{13}\end{array}$ & Awareness & 101 PwD & Longitudinal & $\begin{array}{l}\text { Cognition } \\
\text { Social-emotional }\end{array}$ & $\begin{array}{l}\text { Discrepancies } \\
\text { between } \\
\text { Self-rating and } \\
\text { informant rating }\end{array}$ & $\begin{array}{l}\text { Stability in awareness for the PwD was observed despite } \\
\text { increases in dementia-related symptoms and worsening } \\
\text { of cognitive impairment, and in the context of no change } \\
\text { in psychological or social well-being }\end{array}$ \\
\hline $\begin{array}{l}\text { 26) Mograbi et al., } \\
2012^{49}\end{array}$ & $\begin{array}{l}\text { Awareness of } \\
\text { performance }\end{array}$ & $\begin{array}{l}23 A D \\
21 H C\end{array}$ & Cross-sectional & $\begin{array}{l}\text { Cognition } \\
\text { Social-emotional }\end{array}$ & $\begin{array}{l}\text { Success-failure } \\
\text { manipulation }\end{array}$ & $\begin{array}{l}\text { There is dissociation between impaired performance } \\
\text { judgement and preserved emotional reactivity to failure } \\
\text { in } A D\end{array}$ \\
\hline $\begin{array}{l}\text { 27) Clare et al., } \\
2012^{20}\end{array}$ & Awareness & 101 PwD & Cross-sectional & Cognition & $\begin{array}{l}\text { Discrepancies } \\
\text { between } \\
\text { Self-rating and } \\
\text { informant rating }\end{array}$ & $\begin{array}{l}\text { Indices of awareness and the ratings contributing to } \\
\text { these indices are associated with a range of PwD factors, } \\
\text { as well as being influenced by carer well being and carer } \\
\text { perceptions of PwD }\end{array}$ \\
\hline $\begin{array}{l}\text { 28) Gallo et al., } \\
\text { 2012 }\end{array}$ & Metacognition & $\begin{array}{l}18 \mathrm{AD} \\
18 \mathrm{HC}\end{array}$ & Cross-sectional & Cognition & $A Q-D$ & $\begin{array}{l}\text { AD have relatively preserved metacognitive monitoring } \\
\text { abilities on episodic memory tests, at least when the task } \\
\text { is relatively well constrained }\end{array}$ \\
\hline $\begin{array}{l}\text { 29) Gilleen et al., } \\
2012^{15}\end{array}$ & Awareness & $27 \mathrm{AD}$ & Cross-sectional & $\begin{array}{l}\text { Cognition } \\
\text { Social-emotional } \\
\text { Functional }\end{array}$ & MARS & $\begin{array}{l}\text { Little relationship between awareness and personality } \\
\text { scores, but modest associations between awareness and } \\
\text { mood, age, and age of onset of first symptoms }\end{array}$ \\
\hline $\begin{array}{l}\text { 30) Martyr et al., } \\
\text { 2012 }\end{array}$ & $\begin{array}{l}\text { Awareness of } \\
\text { functioning }\end{array}$ & $\begin{array}{l}50 \mathrm{AD} \\
29 \mathrm{VaD} \\
17 \mathrm{MD}\end{array}$ & Cross-sectional & $\begin{array}{l}\text { Functional } \\
\text { Cognition }\end{array}$ & $\begin{array}{l}\text { Discrepancies } \\
\text { between } \\
\text { Self-rating and } \\
\text { informant rating }\end{array}$ & $\begin{array}{l}\text { Patients with reduced awareness of iADL ability } \\
\text { performed better at letter fluency, indicating that } \\
\text { awareness of functional deficits may be influenced by } \\
\text { letter fluency }\end{array}$ \\
\hline $\begin{array}{l}\text { 31) Spalletta et al., } \\
2012^{31}\end{array}$ & Anosognosia & $\begin{array}{l}103 \mathrm{AD} \\
52 \mathrm{a}-\mathrm{MCl} \\
54 \mathrm{md}-\mathrm{MCl}\end{array}$ & Cross-sectional & Behavioral & $A Q-D$ & $\begin{array}{l}\text { In the mild AD group, unawareness of behavioral deficits } \\
\text { was related to agitation and apathy, whereas global level } \\
\text { of anosognosia, was related to aberrant motor behaviors }\end{array}$ \\
\hline $\begin{array}{l}\text { 32) Arsenault- } \\
\text { Lapierre et al., } \\
2012^{21}\end{array}$ & Anosognosia & $\begin{array}{l}20 \mathrm{MCl} \\
29 \mathrm{AD} \\
20 \mathrm{HC}\end{array}$ & Cross-sectional & Social-emotional & $\begin{array}{l}\text { AQ-D } \\
\text { PSS }\end{array}$ & $\begin{array}{l}\text { Anosognosia for dementia has an impact on psychological } \\
\text { markers of stress, but not on physiological markers of } \\
\text { stress in AD }\end{array}$ \\
\hline $\begin{array}{l}\text { 34) Ohman et al.; } \\
2011^{48}\end{array}$ & $\begin{array}{l}\text { Awareness of } \\
\text { disabilities }\end{array}$ & $\begin{array}{l}8 \mathrm{MCl} \\
18 \mathrm{AD} \\
5 \mathrm{VaD} \\
40 \text { ther dementias }\end{array}$ & Cross-sectional & Functional & $\begin{array}{l}\text { Client-centred } \\
\text { assessment }\end{array}$ & $\begin{array}{l}\text { Participants with the same diagnosis and similar ADL } \\
\text { process ability measures demonstrated major differences } \\
\text { concerning their awareness of disability }\end{array}$ \\
\hline $\begin{array}{l}\text { 35) Amanzio et al., } \\
2011^{44}\end{array}$ & $\begin{array}{l}\text { Reduced } \\
\text { awareness of } \\
\text { deficits }\end{array}$ & $\begin{array}{l}29 A D \\
29 H C\end{array}$ & Cross-sectional & Cognition & $A Q-D$ & $\begin{array}{l}\text { Unaware patients are more impaired in flexible thinking } \\
\text { and demonstrate more pronounced behavioural } \\
\text { disinhibition and apathy with respect to aware ones }\end{array}$ \\
\hline $\begin{array}{l}\text { 36) Galeone et al., } \\
2011^{51}\end{array}$ & $\begin{array}{l}\text { Unawareness for } \\
\text { memory deficit }\end{array}$ & $\begin{array}{l}25 \mathrm{MCl} \\
15 \mathrm{AD} \\
21 \mathrm{HC}\end{array}$ & Cross-sectional & Cognition & $\begin{array}{l}\text { Discrepancies } \\
\text { by comparison } \\
\text { of participants } \\
\text { self-report with } \\
\text { either participant } \\
\text { performance or } \\
\text { informant report }\end{array}$ & $\begin{array}{l}\text { Unawareness for memory deficit in } A D \text { is an early } \\
\text { symptom of their memory disorder and can be seen even } \\
\text { in the } \mathrm{MCl}\end{array}$ \\
\hline $\begin{array}{l}\text { 37) Schmitter- } \\
\text { Edgecombe and } \\
\text { Seelye, } 2011^{55}\end{array}$ & $\begin{array}{l}\text { Awareness of } \\
\text { memory deficits }\end{array}$ & $\begin{array}{l}20 A D \\
20 H C\end{array}$ & Cross-sectional & Cognition & $\begin{array}{l}\text { Discrepancies } \\
\text { between } \\
\text { Self-rating and } \\
\text { informant rating }\end{array}$ & $\begin{array}{l}\text { Impaired awareness of memory problems but intact } \\
\text { memory-monitoring abilities in an AD population }\end{array}$ \\
\hline $\begin{array}{l}\text { 38) Al-Aloucy et } \\
\text { al., 201127 }\end{array}$ & anosognosia & $65 \mathrm{AD}$ & Cross-sectional & Cognition & $\begin{array}{l}\text { Mac nair } \\
\text { Questionnaire } \\
\text { FBI }\end{array}$ & $\begin{array}{l}\text { Anosognosia of memory deficit may be viewed as a } \\
\text { generator of other behavioral abnormalities contributing } \\
\text { to professional caregivers' burden }\end{array}$ \\
\hline $\begin{array}{l}\text { 39) Sousa et al., } \\
2011^{45}\end{array}$ & $\begin{array}{l}\text { Awareness of } \\
\text { disease }\end{array}$ & $25 A D$ & Longitudinal & $\begin{array}{l}\text { Cognition } \\
\text { Functional }\end{array}$ & AISPDD & $\begin{array}{l}\text { As the severity of dementia increases, there is also } \\
\text { impaired awareness of disease, together with } \\
\text { cognitive and functional deficits }\end{array}$ \\
\hline $\begin{array}{l}\text { 40) Nelis et al., } \\
2011^{17}\end{array}$ & Awareness & $\begin{array}{l}51 \mathrm{AD} \\
29 \mathrm{VaD} \\
17 \mathrm{MD}\end{array}$ & Cross-sectional & $\begin{array}{l}\text { Cognition } \\
\text { Social-emotional }\end{array}$ & SEQ & $\begin{array}{l}\text { Unawareness of socio-emotional functioning was related } \\
\text { to poorer cognitive functioning, suggesting a relationship } \\
\text { between stage of dementia and degree of awareness }\end{array}$ \\
\hline $\begin{array}{l}\text { 41) Orfei et al., } \\
2010^{32}\end{array}$ & Anosognosia & $\begin{array}{l}38 \mathrm{AD} \\
35 \mathrm{a}-\mathrm{MCl} \\
38 \mathrm{md}-\mathrm{MCl}\end{array}$ & Cross-sectional & $\begin{array}{l}\text { Cognition } \\
\text { Functional } \\
\text { Behavioral }\end{array}$ & $\begin{array}{l}\text { CIRS } \\
\text { AQ-D }\end{array}$ & $\begin{array}{l}\text { In } A D \text {, anosognosia was linked to increased age and } \\
\text { reduced } A D L \text {. Anosognosia may be primarily affected } \\
\text { by factors other than neuropsychological, such as } \\
\text { neuropsychiatric symptoms }\end{array}$ \\
\hline
\end{tabular}




\begin{tabular}{|c|c|c|c|c|c|c|}
\hline Author/year & Term used & Participants & $\begin{array}{l}\text { Study } \\
\text { Design }\end{array}$ & Domains & $\begin{array}{l}\text { Awareness } \\
\text { measurement }\end{array}$ & Results \\
\hline $\begin{array}{l}\text { 42) Vogel et al., } \\
\text { 201016 }\end{array}$ & Awareness & $321 \mathrm{AD}$ & Cross-sectional & $\begin{array}{l}\text { Cognition } \\
\text { Behavioral }\end{array}$ & ARS & $\begin{array}{l}\text { Alzheimer's disease patients with very poor insight have } \\
\text { significantly more neuropsychiatric symptoms than } \\
\text { patients who are fully aware of their cognitive deficits }\end{array}$ \\
\hline $\begin{array}{l}\text { 43) Stewart et al., } \\
2010^{53}\end{array}$ & $\begin{array}{l}\text { Anosognosia of } \\
\text { memory }\end{array}$ & $\begin{array}{l}23 \mathrm{AD} \\
30 \mathrm{HC}\end{array}$ & Cross-sectional & Cognition & $\begin{array}{l}\text { Measurement } \\
\text { of Anosognosia } \\
\text { instrument }\end{array}$ & $\begin{array}{l}\text { AD patients were generally less accurate in evaluating the } \\
\text { level of their cognitive abilities than healthy older adults }\end{array}$ \\
\hline $\begin{array}{l}\text { 44) Leicht et al., } \\
2010^{29}\end{array}$ & Anosognosia & $32 \mathrm{AD}$ & Cross-sectional & $\begin{array}{l}\text { Cognition } \\
\text { Functional } \\
\text { Social-emotional }\end{array}$ & $\begin{array}{l}\text { CIRS, } \\
\text { discrepancies } \\
\text { by comparison } \\
\text { of participants } \\
\text { self-report with } \\
\text { either participant } \\
\text { performance or } \\
\text { informant report }\end{array}$ & $\begin{array}{l}\text { Discrepancies were especially pronounced for recent } \\
\text { memory, followed by ADL, apathy and attention }\end{array}$ \\
\hline $\begin{array}{l}\text { 45) Williamson et } \\
\text { al., } 2010^{18}\end{array}$ & $\begin{array}{l}\text { Awareness/self- } \\
\text { awareness }\end{array}$ & $\begin{array}{l}10 \mathrm{AD} \\
10 \mathrm{FTD} \\
10 \mathrm{HC}\end{array}$ & Cross-sectional & $\begin{array}{l}\text { Cognition } \\
\text { Functional }\end{array}$ & $\begin{array}{l}\text { discrepancies } \\
\text { between } \\
\text { Self-rating and } \\
\text { informant rating }\end{array}$ & $\begin{array}{l}\text { FTD and AD patients showed impaired self-awareness of } \\
\text { cognitive deficits relative to controls. Comparison across } \\
\text { domains suggested greater distortions in self appraisal in } \\
\text { FTD patients on a task on which they performed slightly } \\
\text { better than the AD patients, and also on tasks on which } \\
\text { they performed less well }\end{array}$ \\
\hline $\begin{array}{l}\text { 46) Starkstein et } \\
\text { al., } 2010^{26}\end{array}$ & Anosognosia & $\begin{array}{l}213 \mathrm{AD} \text { (baseline) } \\
154 \mathrm{AD} \text { (follow-up) }\end{array}$ & Longitudinal & Social-emotional & $A Q-D$ & $\begin{array}{l}\text { Anosognosia and apathy in } A D \text { increased significantly in } \\
\text { severity after a mean period of } 18 \text { months. Anosognosia is } \\
\text { a significant predictor of apathy in AD }\end{array}$ \\
\hline
\end{tabular}

AD: Alzheimer disease; ADL: activities of daily living; a-MCl: Amnestic mild cognitive impairment; A\&A: Anosognosia and Anosodiaphoria scale; AP: amnestic patients; ARS: Anosognosia Rating Scale; ASPIDD: Assessment Scale of Psychosocial Impact of the Diagnosis of Dementia; AQ-D: Anosognosia Questionnaire for Dementia; BCIS: The Beck Cognitive Insight Scale; bvFTD: behavioral variant of Fronto-Temporal Dementia; CAMDEX: Cambridge Mental Disorders of the Elderly Examination; CIRS: Clinical Insight Rating Scale; FBI: Frontal Behavior Inventory; FTD: Fronto-Temporal Dementia; GRAD: Guidelines for the Rating of Awareness Deficits; HC: Healthy Control; LO-AD: late-onset Alzheimer disease; MARS-MFS: the Memory Awareness Rating Scale Memory Functioning Scale; MCl: Mild Cognitive Impairment; md-MCl: amnestic multidomain Mild Cognitive Impairment; na-MCl: non-amnestic mild cognitive impairment; NPI: Neuropsychiatric Inventory; NRS: Neurobehavioral Rating Scale; PD-aMCl: Parkinson disease with Amnestic mild cognitive impairment; PD-ch: Parkinson disease cognitively health; PD-naMCl: Parkinson disease with Amnestic mild cognitive impairment; PSS: Perceived Stress Scale; PwD: People with dementia; QoL: Quality of life; SCD: Subjective cognitive decline; SEQ: Social-emotional Questionnaire; VaD: Vascular Dementia; VSRT: Subtracting Verbal Selective Reminding Test; $Y O-A D$ : young-onset Alzheimer disease.

\section{DISCUSSION}

The different concepts highlight the lack of clear definitions to its boundaries. They are problematic because they contribute to the variability and inconsistency of findings in the area. The conceptual heterogeneity used to define the awareness phenomenon is caused both by the researcher's theoretical perspectives and by the dementia studies from different fields such as Psychology, Psychiatry and Neurology 6 . Therefore, different perspectives coexist when referring to awareness, and it may explain the use of multiple terms for its definition. The concepts are often nonspecific and do not, consider the possible particularities of each terminology.

There were degrees of awareness across the cognitive domain. Questionnaires of discrepancy between PwD and caregivers reports were especially sensitive for recent memory, followed by functional activities, apathy and attention ${ }^{29}$. The association of cognitive deficits with both unawareness of memory and behavior problems domains indicated that cognition may be a basis for self-insight and self-awareness. Thus, cognitive deficits may lead to global unawareness ${ }^{42}$.

A negative association between awareness and MiniMental State Examination (MMSE) suggested that awareness increased as global cognitive functions declined. This finding supported the view that low awareness was related to advanced disease stages ${ }^{30}$. Conversely, a longitudinal assessment of a group of PwD (Alzheimer's disease, vascular dementia and mixed dementia) presented that initial discrepancies were moderate in relation to memory. Surprisingly, there were no changes in discrepancy scores over time. PwD stability in awareness was observed, although the dementia symptoms and the cognitive impairment increase in the context of no change in psychological or social well-being ${ }^{13}$.

Another longitudinal research described that impaired awareness of disease was associated to cognitive and functional deficits at baseline ${ }^{45}$. However, in the second evaluation, awareness remained stable in a proportion of PwD and was followed by a relative decline, which is not only due to the cognitive impairment. Thus, deficits in awareness and cognition seem to be relatively independent, because mild PwD unawareness is mainly manifested by poor recognition on changes in functional activities?.

Van Vliet et al. ${ }^{12}$ concluded that memory deficits are unlikely to explain impaired awareness, as mild PwD can display impaired awareness and PWD with severely disturbed memory retention and consolidation may still have intact awareness. Clinically, unawareness of memory deficit among people with $A D$ was associated with lower scores on the 
MMSE and higher scores on the Cornell Scale for Depression in Dementia. So, depression may occur among people with higher levels of awareness as an emotional response to cognitive declines ${ }^{42}$.

Awareness of cognitive deficits had association with general neuropsychological variables ${ }^{15}$. There were strongest associations with memory, but small significant correlations were also observed for attention, language and executive function. This finding suggested that memory was not the only cognitive domain influencing memory awareness ${ }^{54}$. An important aspect is that unawareness of memory deficit may be understood as an initiator of other behavioral abnormalities contributing to professional caregivers' burden ${ }^{27}$.

Interestingly, unawareness of memory deficit in AD subjects is an early symptom of their memory disorder, even in mild cognitive impairment $(\mathrm{MCl})$. Thus, unawareness might be considered as a specific marker of the transition from $\mathrm{MCl}$ to AD. It is important to note that unawareness for memory deficit may be easily identified in standard clinical setting and used to evaluate the role of unawareness in predicting conversion from $\mathrm{MCl}$ to $\mathrm{AD}^{51}$.

A study ${ }^{47}$ investigated the eventual existence of relationship between awareness and Clinical Competence (CC) in mild to moderate AD. A great proportion of PwD were unaware of cognitive, functional and behavioral deficits, with an increase of severity and prevalence of awareness along the progression of disease. Even people with very mild dementia and great awareness showed substantial deficits in CC. We can assume that deficits in executive function, memory and language may refer to the association between capacity and awareness, suggesting that these two constructs may be differently impaired in $\mathrm{PWD}^{47}$.

On self-evaluating their predictions, people with $A D$ were generally less accurate in evaluating the level of their cognitive abilities than healthy older adults, significantly overestimating their performance on the pretest ${ }^{19,53,55}$. However, immediately after taking the test, people with $A D$ were able to successfully modify their predictions based on task experience, demonstrating self-monitoring memory abilities ${ }^{53,55}$. Those AD participants who continued to exhibit poorer post experience prediction accuracy also tended to more significantly underestimate the frequency of everyday memory difficulties, when compared to caregivers report ${ }^{55}$. The association of the self-evaluating of actual performance with fluency and visuospatial abilities may reinforce the notion that unawareness is in part a neurocognitive deficit. The frontal lobes may be responsible for important processes in awareness, such as evaluating beliefs, monitoring errors or comparing current with past performance ${ }^{50}$. Thus, participants with mild AD were able to use confidence judgments to track the accuracy of their responses on a recollection test. Confidence-accuracy relationship was not impaired in the early stages of $A D$ as PwD have relatively preserved metacognitive monitoring abilities on episodic memory tests, at least when the task was relatively well constrained ${ }^{41}$.

Quality of life (QoL) is considered an indicator of the effectiveness of both psychosocial and pharmacological interventions. Studies suggested an association between unawareness and QoL. The discrepancy between self-report/caregiver reports showed that higher levels of unawareness led PwD to have a more positive view of their QoL, despite their general deterioration ${ }^{23}$. This lack of awareness regarding their actual status suggests that PwD perceptions correspond to a mental image of themselves prior to their deterioration. In addition, Clare et al. ${ }^{20}$ endorse that two domains of awareness - evaluative judgments of memory function and evaluative judgments of functional abilities - show small to medium correlations with self-reported QoL-AD, with higher levels of awareness related to lower QoL.

Awareness of social-emotional functioning elicits quite complex judgments. It occurs because PwD are not asked about a loss or impairment of 'function' as in the case of the memory or activities items; in fact, they are asked about their behaviors, personality, and views of themselves and their perspectives ${ }^{19}$. The judgments entailed in awareness of social-emotional functioning included wider-based judgments and perspectives. It is not surprising that higher levels of differences between subjects and carers were obtained, both in over- and under-estimations ${ }^{19}$.

Unawareness of social-emotional functioning was related to poorer cognitive performance, suggesting a relationship between dementia severity and degree of awareness in this domain ${ }^{19}$. In addition, loss of awareness of social-emotional skills was associated with the presentation and severity of behavioral and psychiatric disturbance in people with $A D^{17}$. A significant relationship between self-reported QoL and the level of awareness in the three areas of social-emotional functioning (emotional recognition and empathy, social relationships and prosocial behavior) was also observed ${ }^{17}$.

In an assessment of a group of people with AD at three moments over approximately 20 months, discrepancies were initially least pronounced in relation to social-emotional functioning, with no changes over time ${ }^{26}$. Concerning emotional reactivity, non-conscious processing of emotion might extend to more complex feelings and attributions, such as frustration/disappointment after task failure and satisfaction after task success. However, there was dissociation between impaired performance judgment and preserved emotional reactivity to failure in $A D^{49}$.

The phenomenon of unawareness affects not only deficits in cognition and daily functioning, but it can also manifest itself as non-recognition of affective symptoms. For example, PwD may be unaware of their depressive symptoms or anxiety in the sense of an "affective" unawarenes ${ }^{24}$. Depression and unawareness were inversely correlated 
among PwD, as unawareness was associated with a more positive self-appraisal among them and its presence increased with the progression of $A^{22}$.

We found only one study of awareness in young onset dementia. Longitudinally, people with young onset AD presented higher levels of awareness compared with late onset AD. A possible explanation was related to the higher levels of environmental demands faced daily by younger people, which may improve awareness of their limitations. Thereby, higher levels of awareness were associated with a higher risk of depressive symptoms and intact awareness was associated with depressive symptoms, an effect more pronounced in young onset compared with late onset dementia ${ }^{12}$. It is necessary to improve the studies in this area, to better understand if there are differences in the objects of awareness in young onset when compared to late onset dementia.

In relation to the perceived stress, unawareness had an impact on psychological markers of stress, but not on the physiological one (i.e. cortisol levels). An explanation was the small sample size of the study and the high variability of cortisol measurements across the days and seasons. It also explained the failure to find statistically significant group differences ${ }^{21}$. Thus, a certain level of perceived stress in AD may cause some problems due to the inability of PwD to be aware of their cognitive state ${ }^{21}$.

Neuropsychiatric symptoms are factors that contribute to unawareness, besides the neuropsychological aspects. In people with AD, unawareness of psychosis or behavior problems was related with lower scores on the MMSE and may be more prevalent or more severe as dementia progresses $^{42}$. PwD with very poor awareness had significantly more neuropsychiatric symptoms than people who were fully aware of their cognitive deficits ${ }^{16}$. PwD with unawareness presented deficits in functional activities and higher levels of behavioral and psychological symptoms of dementia such as disinhibition, apathy, irritability and anxiety, agitation, and aberrant motor behavior ${ }^{25}$.

In mild $A D$, there was a relationship between unawareness of behavioral deficits and agitation and apathy, whereas global level of anosognosia was related to aberrant motor behaviors. The diagnosis of unawareness has been associated with severity of apathy symptoms as well as the categorical diagnosis of the apathy disorder ${ }^{31}$. A longitudinal assessment, during the first year, showed a decline in awareness score, which was not associated with change in any of the studied variables. However, neuropsychiatric symptoms of people with lower awareness after 36 months (as compared to baseline) increased, when compared to individuals with improved or stable awareness ${ }^{14}$.

The ability to inhibit a response, self-monitoring, and set-shifting appears to be important executive functions for awareness of functional deficits in $A D^{43}$. Set-shifting and pro- cessing speed may have a role in awareness, but are likely to be part of a multicomponent process ${ }^{15}$. PwD showed decreased awareness of deficits in activities requiring executive function, such as handling money, practicing favorite hobbies and doing home activities ${ }^{34}$. In moderate AD, deficits in self-awareness were also apparent in the activities regarding communication and social interaction, such as communicating with people, or understanding conversations, the newspaper and the plot of a movie that involves communication of characters ${ }^{34}$. Ohman et al. ${ }^{48}$ reported individual variations of awareness of disability in participants with the same diagnosis and similar functional activities process skills measures. Several other factors (e.g. denial, or having experienced the problems in functional activities performances over a long period) may also impact on PwD experiences and descriptions of functional activities performance and, hence, may result as well in lower scores in the awareness evaluation ${ }^{48}$.

PWD tend to overestimate the awareness of functional activities $^{19}$. Appraisal of daily activities possibly evokes judgments that are more straightforward than those involved in hypothetical memory tasks. The overestimation indicated that participants seemed to show more unawareness in relation to assessing their abilities to do specific tasks than in assessing their abilities to remember particular thing ${ }^{19}$.

From a discrepancy analysis between PwD and caregivers reports, PwD with reduced awareness of instrumental functional activities ability performed better at letter fluency, indicating that awareness of functional deficits may be influenced by letter fluency ${ }^{46}$.

This systematic review has some limitations. We included studies that were not controlled and randomized. In addition, we selected studies that assessed only people with AD, which unable the observation of the particularities of awareness in different dementia etiologies. Despite these limitations, we add to literature emphasizing that the clinical phenomenon of awareness is determined to some extent by the "object" of awareness assessment. This means that there is a great need for more studies and further researches in this area, especially longitudinal studies that clearly define the assessed object and its specificities.

\section{CONCLUSIONS}

Even though many researches investigate the concept of awareness, the results are variable and inconsistent. Awareness is a complex and multidimensional construct, which needs to be carefully defined. Different objects elicit different levels of awareness. Therefore, the findings may change in relation to the chosen concept and according with the specific selected object of awareness.

The comparison between the studies shows the emphasis on cognitive domain in the assessments. Interestingly, the 
findings of the cross-sectional studies between awareness and, more specifically, the cognitive domain were not observed in the longitudinal ones. Over time, awareness may improve or may remain stable for a considerable proportion of PwD, suggesting that there is no straightforward relationship with dementia severity or with the progression of cognitive impairments.

Furthermore, there are controversies about the role of the cognitive components in decreased awareness. Memory deficits are not sufficient to explain impaired unawareness, although a strong association has been observed between awareness and the memory domain. The relationship observed between awareness and attention, language and executive function suggests that memory is not the only cognitive domain that influence awareness. In addition, the inclusion of different subtypes of dementias may originate a lack of specificity, since different etiologies may lead to different cognitive and functional symptomatology, in which different domains of awareness may be affected. Moreover, the sociodemographic variables should be observed.

The Diagnostic and Statistical Manual of Mental Disorders, Fifth Edition (DSM-5) ${ }^{57}$ has recently included social cognition as a criterion that composes the basis for the diagnosis of dementia. Awareness of social-emotional functioning and behavioral impairment is a domain, which elicits complex judgements, regarding emotion recognition. Most studies investigate the cognitive and functional domains, but there is a need to further research on the recognition of social-emotional functioning. Lack of awareness of social-emotional functioning may cause relevant implications involving social comprehension and communication that can also lead to higher levels of carer burden and stress.

\section{INDIVIDUAL CONTRIBUTIONS}

Isabel B. Lacerda - Performed the literature search and wrote most of the manuscript.

Maria Fernanda B. Sousa - Assisted with writing the manuscript and independently screened titles and abstracts to identify eligible papers.

Raquel L. Santos and Marcela M. L. Nogueira - Independently extracted information from the selected publications and corrected the article's draft.

Marcia C. N. Dourado - Guided the conception for the review and the process of performing the literature search, and edited the manuscript.

\section{CONFLICT OF INTEREST}

None.

\section{REFERENCES}

1. Sousa MFB, Santos RL, Nogueira ML, Belfort T, Dias R, Torres B, et al. wareness of disease is different for cognitive and functional aspects in mild Alzheimer's disease: a one-year observation study. J Alzheimers Dis. 2015;43(3):905-13.

2. Dourado M, Marinho V, Soares C, Engelhardt E, Laks J. Awareness of disease in Alzheimer's dementia: description of a mild to moderate sample of patient and caregiver dyads in Brazil. Int Psychogeriatr. 2007;19(4):733-44.

3. Clare L. The construction of awareness in early-stage Alzheimer's disease: a review of concepts and models. Br J Clin Psychol. 2004;43(Pt 2):155-75.

4. Dourado MCN, Marinho V, Soares C, Engelhardt E, Laks J. Awareness of disease in dementia Development of a multidimensional rating scale. Dement Neuropsychol. 2007;1(1):74-80.

5. Marková IS, Berrios GE. The 'object' of insight assessment: relationship to insight 'structure'. Psychopathology. 2001;34(5):245-52.

6. Marková IS, Clare L, Whitaker CJ, Roth I, Nelis SM, Martyr A, et al. Phenomena of awareness in dementia: heterogeneity and its implications. Conscious Cogn. 2014;25:17-26.

7. Marková IS, Clare L, Wang M, Romero B, Kenny G. Awareness in dementia: conceptual issues. Aging Ment Health. 2005;9(5):386-93.

8. Clare L. Awareness in people with severe dementia: review and integration. Aging Ment Health. 2010;14(1):20-32.

9. Aalten P, van Valen E, Clare L, Kenny G, Verhey F. Awareness in dementia: a review of clinical correlates. Aging Ment Health. 2005;9(5):414-22.

10. Dourado MC, Mograbi DC, Santos RL, Sousa MF, Nogueira ML, Belfort T, et al. Awareness of disease in dementia: factor structure of the assessment scale of psychosocial impact of the diagnosis of dementia. J Alzheimers Dis. 2014;41(3):947-56.

11. Moher D, Liberati A, Tetzlaff J, Altman DG; PRISMA Group. Preferred reporting items for systematic reviews and meta-analyses: the PRISMA statement. PLOS Med. 2009;6(7):e1000097.

12. van Vliet D, de Vugt ME, Köhler S, Aalten P, Bakker C, Pijnenburg YA, et al. Awareness and its association with affective symptoms in young-onset and late-onset Alzheimer disease: a prospective study. Alzheimer Dis Assoc Disord. 2013;27(3):265-71.

13. Clare L, Nelis SM, Martyr A, Whitaker CJ, Marková IS, Roth I, et al. Longitudinal trajectories of awareness in early-stage dementia. Alzheimer Dis Assoc Disord. 2012;26(2):140-7.

14. Vogel A, Waldorff FB, Waldemar G. Longitudinal changes in awareness over 36 months in patients with mild Alzheimer's disease. Int Psychogeriatr. 2015;27(1):95-102.

15. Gilleen J, Greenwood K, Archer N, Lovestone S, David AS. The role of premorbid personality and cognitive factors in awareness of illness, memory, and behavioural functioning in Alzheimer's disease. Cogn Neuropsychiatry. 2012;17(3):227-45.

16. Vogel A, Waldorff FB, Waldemar G. Impaired awareness of deficits and neuropsychiatric symptoms in early Alzheimer's disease: the Danish Alzheimer Intervention Study (DAISY). J Neuropsychiatry Clin Neurosci. 2010;22(1):93-9.

17. Nelis SM, Clare L, Martyr A, Markova I, Roth I, Woods RT, et al. Awareness of social and emotional functioning in people with early-stage dementia and implications for carers. Aging Ment Health. 2011;15(8):961-9.

18. Williamson C, Alcantar O, Rothlind J, Cahn-Weiner D, Miller BL, Rosen HJ. Standardised measurement of self-awareness deficits in FTD and AD. J Neurol Neurosurg Psychiatry. 2010;81(2):140-5.

19. Markova IS, Clare L, Whitaker CJ, Roth I, Nelis SM, Martyr A, et al. Phenomena of awareness in dementia: Heterogeneity and its implications. Conscious Cogn. 2014r;25:17-26.

20. Clare L, Nelis SM, Martyr A, Roberts J, Whitaker (J, Markova IS, et al. The influence of psychological, social and contextual factors on the expression and measurement of awareness in early-stage dementia: testing a biopsychosocial model. Int I Geriatr Psychiatry. 2012;27(2):167-77.

21. Arsenault-Lapierre G, Whitehead V, Lupien $\mathrm{S}$, Chertkow H. Effects of anosognosia on perceived stress and cortisol levels in Alzheimer's disease. Int J Alzheimers Dis. 2012;2012:1-7.

22. Conde-Sala UL, Reñé-Ramírez R, Turró-Garriga 0, Gascón-Bayarri J, Campdelacreu-Fumadó J, Juncadella-Puig $\mathrm{M}$, et al. Severity of dementia, anosognosia, and depression in relation to the quality of life of patients with Alzheimer disease: discrepancies between patients and caregivers. Am J Geriatr Psychiatry. 2014;22(2):138-47. 
23. Conde-Sala JL, Turró-Garriga 0, Garre-Olmo J, Vilalta-Franch J, Lopez-Pousa S. Discrepancies regarding the quality of life of patients with Alzheimer's disease: a three-year longitudinal study. J Alzheimers Dis. 2014;39(3):511-25.

24. Verhülsdonk S, Quack R, Höft B, Lange-Asschenfeldt C, Supprian T. Anosognosia and depression in patients with Alzheimer's dementia. Arch Gerontol Geriatr. 2013;57(3):282-7.

25. Conde-Sala JL, Reñé-Ramírez R, Turró-Garriga 0, Gascón-Bayarri J, Juncadella-Puig M, Moreno-Cordón L, et al. Clinical differences in patients with Alzheimer's disease according to the presence or absence of anosognosia: implications for perceived quality of life. J Alzheimers Dis. 2013:33(4):1105-16.

26. Starkstein SE, Brockman S, Bruce D, Petracca G. Anosognosia is a significant predictor of apathy in Alzheimer's disease. J Neuropsychiatry Clin Neurosci. 2010;22(4):378-83.

27. Al-Aloucy MJ, Cotteret R, Thomas P, Volteau M, Benmaou I, Dalla Barba G. Unawareness of memory impairment and behavioral abnormalities in patients with Alzheimer's disease: relation to professional health care burden. J Nutr Health Aging. 2011;15(5):356-60.

28. Lindau M, Bjork R. Anosognosia and anosodiaphoria in mild cognitive impairment and Alzheimer's disease. Dement Geriatr Cogn Disord Extra. 2014;4(3):465-80

29. Leicht $H$, Berwig M, Gertz HJ. Anosognosia in Alzheimer's disease: the role of impairment levels in assessment of insight across domains. J Int Neuropsychol Soc. 2010;16(3):463-73.

30. Mak E, Chin R, Ng LT, Yeo D, Hameed S. Clinical associations of anosognosia in mild cognitive impairment and Alzheimer's disease. Int J Geriatr Psychiatry. 2015;30(12):1207-14.

31. Spalletta G, Girardi P, Caltagirone C, Orfei MD. Anosognosia and neuropsychiatric symptoms and disorders in mild Alzheimer disease and mild cognitive impairment. J Alzheimers Dis. 2012;29(4):761-72.

32. Orfei MD, Varsi AE, Blundo C, Celia E, Casini AR, Caltagirone C, et al. Anosognosia in mild cognitive impairment and mild Alzheimer's disease: frequency and neuropsychological correlates. Am J Geriatr Psychiatry. 2010;18(12):1133-40

33. Zamboni G, Drazich E, McCulloch E, Filippini N, Mackay CE, Jenkinson M, et al. Neuroanatomy of impaired self-awareness in Alzheimer's disease and mild cognitive impairment. Cortex. 2013;49(3):668-78.

34. Maki Y, Amari M, Yamaguchi T, Nakaaki S, Yamaguchi H. Anosognosia: patients' distress and self-awareness of deficits in Alzheimer's disease. Am J Alzheimers Dis Other Demen. 2012;27(5):339-45.

35. Massimo L, Libon DJ, Chandrasekaran K, Dreyfuss M, McMillan CT, Rascovsky K, et al. Self-appraisal in behavioural variant frontotemporal degeneration. J Neurol Neurosurg Psychiatry. 2013;84(2):148-53

36. Horning SM, Melrose R, Sultzer D. Insight in Alzheimer's disease and its relation to psychiatric and behavioral disturbances. Int J Geriatr Psychiatry. 2014;29(1):77-84.

37. Mendez MF, Shapira JS. Loss of emotional insight in behavioral variant frontotemporal dementia or "frontal anosodiaphoria". Conscious Cogn. 2011;20(4):1690-6.

38. Degirmenci E, Degirmenci T, Dügüncü Y, Yilmaz G. Cognitive insight in Alzheimer's disease. Am J Alzheimers Dis Other Demen. 2013;28(3):263-8.

39. Rosen HJ, Alcantar 0, Zakrzewski J, Shimamura AP, Neuhaus J, Miller BL. Metacognition in the behavioral variant of frontotemporal dementia and Alzheimer's disease. Neuropsychology. 2014;28(3):436-47.
40. Mårdh S, Karlsson T, Marcusson J. Aspects of awareness in patients with Alzheimer's disease. Int Psychogeriatr. 2013;25(7):1167-79.

41. Gallo DA, Cramer SJ, Wong JT, Bennett DA. Alzheimer's disease can spare local metacognition despite global anosognosia: revisiting the confidence-accuracy relationship in episodic memory. Neuropsychologia. 2012;50(9):2356-64.

42. Chen YL, Chen HM, Huang MF, Yeh YC, Yen CF, Chen CS. Clinical correlates of unawareness of deficits among patients with dementia due to Alzheimer's disease. Am J Alzheimers Dis Other Demen. 2014;29(6):533-9.

43. Amanzio M, Vase L, Leotta D, Miceli R, Palermo S, Geminiani G. Impaired awareness of deficits in Alzheimer's disease: the role of everyday executive dysfunction. J Int Neuropsychol Soc. 2013;19(1):63-72.

44. Amanzio M, Torta DM, Sacco K, Cauda F, D'Agata F, Duca S, et al. Unawareness of deficits in Alzheimer's disease: role of the cingulate cortex. Brain. 2011;134(Pt 4):1061-76.

45. Sousa MFB, Santos RL, Arcoverde C, Dourado M, Laks J. [Awareness of disease in Alzheimer's disease: preliminary results of a longitudinal study]. Rev Psiquiatr Clin. 2011;38(2):57-60.

46. Martyr A, Clare L, Nelis SM, Marková IS, Roth I, Woods RT, et al. Verbal fluency and awareness of functional deficits in early-stage dementia. Clin Neuropsychol. 2012;26(3):501-19.

47. Gambina G, Bonazzi A, Valbusa V, Condoleo M, Bortolami O, Broggio E, et al. Awareness of cognitive deficits and clinical competence in mild to moderate Alzheimer's disease: their relevance in clinical practice. Neurol Sci. 2014;35(3):385-90.

48. Ohman A, Nygård L, Kottorp A. Occupational performance and awareness of disability in mild cognitive impairment or dementia. Scand J Occup Ther. 2011;18(2):133-42.

49. Mograbi DC, Brown RG, Salas C, Morris RG. Emotional reactivity and awareness of task performance in Alzheimer's disease. Neuropsychologia. 2012;50(8):2075-84

50. Mograbi DC, Ferri CP, Stewart R, Sosa AL, Brown RG, Laks J, et al. Neuropsychological and behavioral disturbance correlates of unawareness of memory impairment in dementia: a population-based study. J Geriatr Psychiatry Neurol. 2015;28(1):3-11.

51. Galeone F, Pappalardo S, Chieffi S, lavarone A, Carlomagno S. Anosognosia for memory deficit in amnestic mild cognitive impairment and Alzheimer's disease. Int J Geriatr Psychiatry. 2011;26(7):695-701.

52. Mograbi DC, Ferri CP, Sosa AL, Stewart R, Laks J, Brown R, et al. Unawareness of memory impairment in dementia: a population-based study. Int Psychogeriatr. 2012;24(6):931-9.

53. Stewart G, McGeown WJ, Shanks MF, Venneri A. Anosognosia for memory impairment in Alzheimer's disease. Acta Neuropsychiatr. 2010;22(4):180-7.

54. Lehrner J, Kogler S, Lamm C, Moser D, Klug S, Pusswald G, et al. Awareness of memory deficits in subjective cognitive decline, mild cognitive impairment, Alzheimer's disease and Parkinson's disease. Int Psychogeriatr. 2015;27(3):357-66.

55. Schmitter-Edgecombe M, Seelye AM. Predictions of verbal episodic memory in persons with Alzheimer's disease. J Clin Exp Neuropsychol. 2011;33(2):218-25.

56. Woods RT, Nelis SM, Martyr A, Roberts J, Whitaker CJ, Markova I, et al. What contributes to a good quality of life in early dementia? Awareness and the QoL-AD: a cross-sectional study. Health Qual Life Outcomes. 2014;12:94.

57. American Psychiatric Association. Diagnostic and statistical manual of mental disorders. 5th ed. Arlington (VA): American Psychiatric Association; 2013. p. 1-948. 